\title{
Dynaaminen rehuarvomalli tarkentaa ravintoaineiden saannin ennustamista
}

\author{
Pekka Huhtanen \\ MTT, Kotieläintuotannon tutkimus, Eläinravitsemus, 31600 Jokioinen, pekka.huhtanen@mtt.fi
}

\section{Johdanto}

Nykyiset märehtijöiden faktoriaaliset rehuarvojärjestelmät kuten meillä käytössä oleva muuntokelpoiseen energiaan (ME) perustuva energiajärjestelmä sekä ohutsuolesta imeytyvään valkuaiseen (OIV) perustuva valkuaisjärjestelmä (www.agronet.fi/rehutaulukot) pohjautuvat olettamukseen, että rehujen ravintoarvot ovat vakiot riippumatta ruokintatasosta ja rehuannoksen koostumuksesta eli rehuarvojen oletetaan olevan additiivisia. Toisaalta on jo kauan tiedetty, että ruokintatason noustessa rehuannoksen sulavuus huononee ja että ruokintatason vaikutus sulavuuteen riippuu rehuannoksen koostumuksesta. Sulavuuden aleneminen ruokintatason noustessa lisääntyy väkirehun osuuden noustessa ja tästä syystä rehuannoksen sulavuus on lypsylehmillä jokseenkin riippumaton väkirehun osuudesta. Samaten suurten rasva-annosten tiedetään vaikuttavan haitallisesti kuidun sulavuuteen. Toisaalta valkuaisrehut parantavat kuidun sulavuutta, kun pötsimikrobien typen saanti on riittämätöntä - mahdollisesti myös tämän jälkeenkin. Rehujen komponenttien välillä on siten merkittäviä yhdysvaikutuksia ja yksittäisellä rehulla voi siten teoriassa olla ääretön määrä erilaisia rehuarvoja riippuen siitä, minkälaisessa rehuyhdistelmässä sitä käytetään.

Faktoriaalisia systeemejä voidaan jonkin verran kehittää ottamalla niihin uusia elementtejä, mutta kehitysmahdollisuudet ovat kuitenkin rajalliset. Esimerkiksi Tanskassa laskennallinen rehuyksikköjen saanti korjataan vastaamaan ko. ruokintatason tilannetta toisen asteen regressioyhtälön avulla, mutta tämän tyyppisten korjaustekijöiden laajempi soveltaminen voi olla ongelmallista; erityisesti kun ollaan aineiston ulkopuolella.

Vaikka Pohjoismaiden yhteisillä järjestelmillä olisi tiettyjä etuja, hintana tästä olisi todennäköisesti se, että jokaisessa maassa olisi käytössä todennäköisesti huonompi systeemi kuin tämänhetkiset systeemit. Näissä voidaan hyödyntää oman maan tietoa ja kokemusta paremmin kuin yhteisessä systeemissä.

Pohjoismaissa otettiin lähtökohdaksi täysin uudentyyppisen dynaamiseen mekanistiseen mallintamiseen perustuvan systeemin kehittäminen. Työtä on tehty NKJ-111 -hankeen puitteissa. Tavoitteena on, että hankkeen loppuessa meillä on neuvonnan, opetuksen ja tutkimuksen käytössä malli, joka ennustaa rehuannosten ravintoaineiden saannin ja tuotantovaikutuksen vähintään yhtä hyvin kuin nykyiset systeemit.

\section{Karoline-malli}

NKJ-111 -hankkeen tuloksena syntyvä dynaaminen, deterministinen ja mekanistinen mallilehmä on saanut nimekseen Karoline. Dynaaminen tarkoittaa sitä, että malli perustuu differentiaaliyhtälöihin, jotka ovat muotoa: $\mathrm{dx} / \mathrm{dt}=\mathrm{f}(\mathrm{a}, \mathrm{b}, \mathrm{c}), \mathrm{ja}$ jotka integroidaan ajan suhteen. Nykyiset mallit ovat staattisia eli ne esim. ennustavat ravintoaineiden saannin tietyllä hetkellä lehmälle, joka on tietyn painoinen, tuottaa tietyn määrän maitoa jne. Staattiset mallit ovat myös faktoriaalisia eli ravintoaineen tarve on esim. ylläpidon, aktiviteetin, tiineyden ja maidontuotannon tarpeiden summa. Arvioitaessa dieetin tuotantovaikutus oletetaan, että tarpeet ovat ehdottoman hierarkkisia eli ylläpito ennen aktiviteettia, aktiviteetti ennen tiineyttä, tiineys ennen maidontuotantoa ja että näiden välillä ei ole mitään yhdysvaikutuksia.

Deterministinen malli tarkoittaa sitä, että mallin yhtälöiden ratkaisut ovat tarkkoja ja että parametrien arvoissa ei ole todennäköisyyksin perustuvaa vaihtelua eli mallin ratkaisuja voidaan soveltaa eläinryhmälle - ei välttämättä yksittäiselle eläimelle, jolla voi olla esim. normaalia pitempi viipymisaika pötsissä tai pienempi perusaineenvaihdunnan taso.

Mekanistinen malli tarkoittaa sitä, että yhtälöillä kuvataan vaikuttavat ilmiöt ja mekanismit; esim. sulavan kuidun (DNDF) sulavuus rehun sulatus - ja virtauskinetiikan avulla (Kuvio 1). Nykyiset mallit puolestaan perustuvat empiirisiin riippuvuussuhteisiin, jotka on havaittu kahden tai useamman muuttujan välillä. Näillä tilastollisilla rïppuvuussuhteilla ei välttämättä ole mitään tekemistä taustalla olevien vaikutusmekanismien kanssa. 


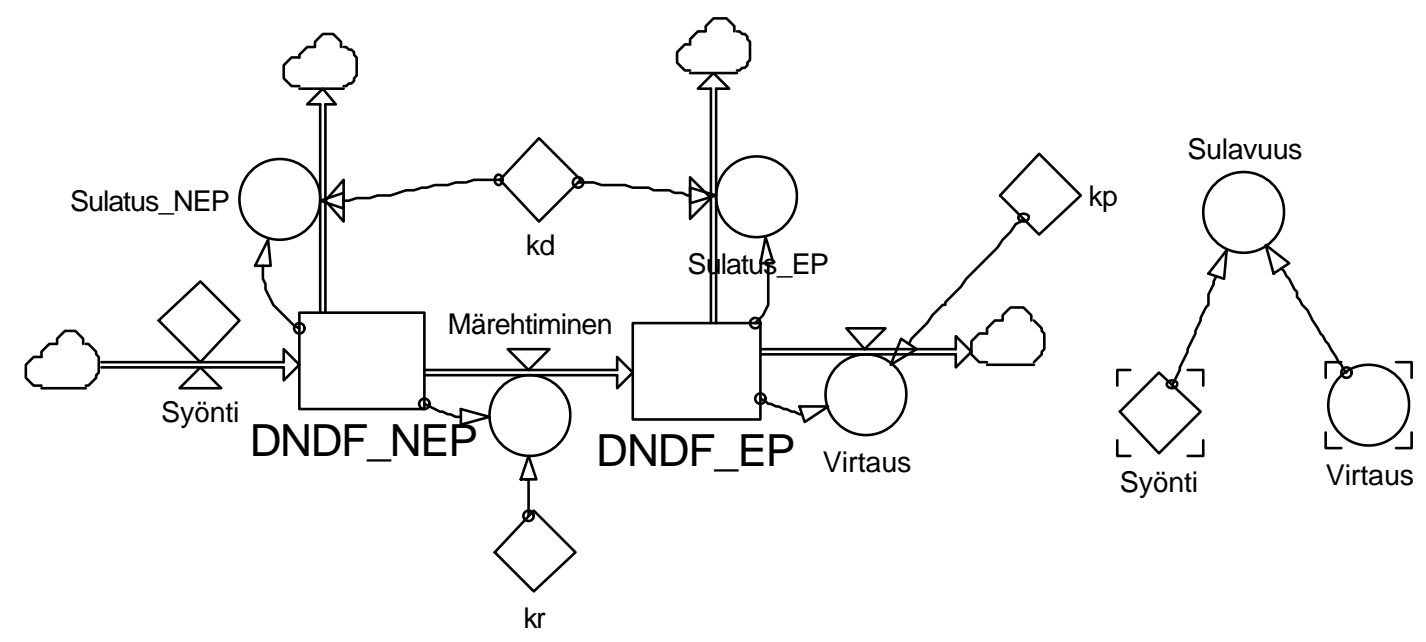

Kuvio 1. Dynaaminen malli DNDF:n pötsisulatuksesta.

Karoline-mallissa on kuvattu kuviossa 1 esitetyllä tavalla rehun sulatusta ja ravintoaineiden aineenvaihduntaa kuvaavat mekanismit. Malli on kooltaan varsin suuri, sillä sen graafiseen kuvaamiseen on tarvittu 54 sivua ja siinä on yhteensä noin 1000 poolia, virtausta, apumuuttujaa ja vakiota, kun niitä kuvan mallissa on yhteensä 11 . Simulointi-intervalli on $0.1 \mathrm{~h}$ ja simulointiaika $700 \mathrm{~h}$ eli yhteensä laskutoimitukset tehdään 7000 kertaa tasapainotilan saavuttamiseksi.

\section{Mallin toiminta}

Malli on rakennettu graafisella POWERSIM ${ }^{\circledR}$-ohjelmalla. Tarvittavat alkutiedot (rehun koostumus, syönti, elopaino, sulatus- ja virtauskinetiikan parametrejä ym.) siirretään Excel-tiedostosta, johon myös tulostetaan haluttavat simulaatiotulokset. Mallin on varsin käyttäjäystävällinen eikä sen käyttö edellytä Karolinen sisäisen rakenteen tuntemusta. Mallista on olemassa myös DEMO-versio internetissä (www.njfjord.dk) . Tulevaisuudessa neuvojat voivat käyttää mallia internetin välityksellä syöttämällä omia rehu- ja eläintietoja.

Karoline vaatii rehuista nykyistä enemmän tietoa, mutta toisaalta kaikki nykyisten rehutaulukoiden tieto ei ole tarpeen (raakakuitu, typettömät uuteaineet, sulavuuskertoimet, HVO, OIV, PVT, ME). Karoline jakaa rehun orgaanisen aineen ensin kolmeen osaan: hiilihydraatit, raakavalkuainen ja raakarasva. Hiilihydraatit jaetaan edelleen seuraavasti: väkirehun sulava (DNDF) ja sulamaton NDF (INDF), karkearehun DNDF ja INDF, tärkkelys, sokerit (jäännösfraktio), maitohappo, etikkahappo ja propionihappo. Haihtuvat rasvahapot (VFA) siirtyvät käymisen lopputuotteina suoraan ko. hapon pooliin pötsissä. Väkirehun ja karkearehun NDF on kuvattu erikseen sen vuoksi, että rehujen virtauskinetiikat poikkeavat toisistaan ja myös pötsikäymisessä muodostuu lopputuotteita eri suhteissa. Maitohappo on mukana omana poolinaan sen vuoksi, että se on tärkein yksittäinen pötsin VFA-suhteisiin vaikuttava tekijä ja pötsimikrobien energian saanti maitohaposta poikkeaa sekä muista hiilihydraateista että VFA:sta.

Sokerit (jäännösfraktio) on tietyssä mielessä ongelmallinen, koska se lasketaan erotuksena muista hiilihydraateista ja pitää sisällään myös muita komponentteja kuin varsinaista sokeria (esim. pektiini, kasvihapot, etanoli). Näistä pötsikäymisessä muodostuneiden happojen suhteet ja mikrobien energian saanti voivat vaihdella. Toisaalta näiden kaikkien todellinen sulavuus on $100 \%$ ja osuus dieetin kuiva-aineesta varsin pieni. Ravintoaineiden saannin ennustamiseksi tarvitaan joka tapauksessa erotuksella laskettava fraktio, koska millään nykyisin käytössä olevilla analyysimenetelmillä komponenttien summaksi ei tule $100 \%$. On myös syytä huomata, että Karolinen jäännösfraktio on oleellisesti pienempi ja homogeenisempi kuin nykyisen systeemin jäännösfraktio typettömät uuteaineet (sokerista ligniiniin), joka voi enimmillään olla moninkertainen analysoituihin komponentteihin verrattuna.

Pitoisuuksien lisäksi rehujen hiilihydraateista tarvitaan sulatusnopeudet $\left(k_{d}\right)$ eli se osuus, mikä ko. fraktiosta sulaa aikayksikköä kohti (esim 0.05 tarkoittaa, että seuraavan tunnin aikana rehun komponentista sulaa $5 \%$ ja tunnin päästä alkuperäisestä on jäljellä $95 \%$ ). Karkearehun ja väkirehun DNDF:n $k_{d}$ ovat tärkeimmät. Tärkkelyksen $k_{d}$ on mallissa vakio 0.25 , mutta on myös mahdollista käyttää poikkeavia nopeuksia esim. maisille ja prosessoiduille rehuille. Sokerin ja maitohapon osalta käytetään vakioarvoja. Nämä 
fermentoituvat joka tapauksessa niin nopeasti, että ravintoaineiden saannin kannalta mahdollisella vaihtelulla ei ole merkitystä. INDF:n sulatusnopeus on määritelmän mukaan nolla.

Input-datan DNDF:n $k_{d}$ :n arvot ovat ko. rehulle ominaisia potentiaalisia sulatusnopeuksia eli niiden saavuttaminen edellyttää kuidun sulatuksen kannalta optimaaliset olosuhteet. Tätä $k_{d}$ :n arvoa korjataan ns. $\mathrm{k}_{\mathrm{d}^{-}}$ faktorilla, joka optimiolosuhteissa saa arvon $1.00 . \mathrm{K}_{\mathrm{d}}$-faktori on rehun solunsisällyshiilihydraattien ja NDF:n suhteen eksponentiaalinen funktio eli rehun $k_{d}$ :n arvo huononee väkirehun osuuden lisääntyessä. Tämän mekanismin avulla on onnistuttu kuvaamaan rehun sulatuksen negatiiviset yhdysvaikutukset varsin hyvin.

Hiilihydraattien viipymisaikaa pötsissä säätelee NDF:n syönti elopainokiloa kohti eli ruokintatason noustessa rehun viipymisaika lyhenee ja sulavuus huononee. Hiilihydraattien sulatuksen lopputuotteina muodostuu VFA:ta ja kaasuja. Mallia voidaan käyttää mm. metaanin tuotannon estimointiin.

Rehun typellinen osa eli raakavalkuainen kuvataan kuudella fraktiolla: ammoniakki, vapaat aminohapot, peptidit, liukoinen valkuainen, liukenematon valkuainen ja sulamaton valkuainen. Näistä neljä ensimmäistä muodostaa ns. $a$-fraktion nailonpussimenetelmässä, liukenematon valkuainen on $b$-fraktio ja sulamaton vastaa $100-(a+b)$. Valkuaisen hajoamisen mallintamisessa on otettu proteolyysin välivaiheet huomioon eli että liukenematon valkuainen muuttuu ensin liukoiseksi, joka hajoaa ensin peptideiksi, sitten aminohapoiksi ja lopulta ammoniakiksi. Liukoista aminotyppeä virtaa pötsistä ulos aminohappoina, peptideinä ja liukoisena valkuaisena. Tätä ns. liukoista ohitusvalkuaista nykyiset systeemit eivät ota huomioon lainkaan.

Mikrobivalkuaisen tuotanto riippuu pötsikäymisessä muodostuvan energian määrästä, mikrobien ylläpitoenergian tarpeesta sekä mikrobien virtausnopeudesta, joka on pötsin partikkeli- ja nestefaasin virtausnopeuksien painotettu keskiarvo. Mikrobisynteesi tehostuu ruokintatason noustessa, koska virtausnopeus lisääntyy ja vähemmän energiaa tarvitaan mikrobien ylläpitoon. Mikrobipoolin koko ja dieetin koostumus säätelevät yläpitotarvetta (helppoliukoisia hiilihydraatteja käyttävien mikrobien ylläpitotarve on suurempi kuin kuitua sulattavien). Hajoavan valkuaisen saanti rupeaa rajoittamaan mikrobisynteesiä, kun pötsin ammoniakkipitoisuus on alle $50 \mathrm{mg} \mathrm{N} / \mathrm{L}$. Typen sisäinen kierto on mallissa otettu huomioon.

Rehun komponenttien sulatus ohutsuolessa on kuvattu entsyymikinetiikan avulla. Paksusuolen sulatus on kuvattu samalla tavalla kuin pötsisulatus. Malli ottaa huomioon myös endogeenisen ja metaboolisen aineksen erityksen sontaan.

Rasvan sulatus mallinnetaan rasvahappoina, koska ainoastaan rasvahappoina imeytynyttä voidaan käyttää kudosten rasvametaboliassa. Dieetin raakarasva muutetaan rasvahapoiksi empiiristen yhtälöiden avulla. Osa raakarasvan ja rasvahappojen erotuksesta menee suoraan pötsin VFA-pooleihin, osa lisätään jäännösfraktioon ja sulamaton osa (7 g/kg ka; esim. vahat) suoraan sontaan.

\section{Mallin testaaminen}

Mallia rakennettaessa sitä on jatkuvasti testattu in vivo aineistolla. Mallia on testattu sekä yksinkertaisella regressioanalyysillä että sekamallin (mixed-model) regressioanalyysillä. Jälkimmäisessä koe on ollut satunnaistekijä. Tällä eliminoidaan esim. erilaisten koetekniikoiden, eläinten ja analyysimenetelmien vaikutus in vivo tuloksiin ja pystytään paremmin analysoimaan sitä, onko malli ennustanut dieettien väliset erot kokeen sisällä oikein. Usein ajatellaan, että vika on mallissa simuloidun ja havaitun tuloksen poiketessa toisistaan. Näin voi usein olla, mutta ei suinkaan välttämättä. Mitä monimutkaisemmista koetekniikoista on kyse, sitä suuremmat virhemahdollisuudet mitatuissa arvoissa on. Hyvin huolellisesti tehdyissä kokeissakin on aina selittämätöntä vaihtelua, ja jos havaintopisteet ovat kapealla alueella, mallin selitysaste ei välttämättä ole kovin suuri vaikka ennustevirhe olisi kohtuullinen. Tästä syystä olisi hyvä tarkastella, miten simuloidut havainnot vastaavat mitattuja otettaessa jälkimmäisessä huomioon koevirheen aiheuttama luottamusväli.

Toinen merkittävä tekijä, joka voi johtaa virheellisiin päätelmiin mallin toimivuudesta on virheelliset rehujen parametriarvot. Jos esim. karkearehun NDF:n sulatusnopeudet on systemaattisesti aliarvioitu (esim. perustuvat nailonpussimenetelmään), niin simuloidut ja mitatut arvot poikkeavat toisistaan vaikka malli olisi oikea ja myös mittaukset tehty oikein. Tässä tapauksessa mallin selitysaste olisi hyvä, mutta harha = havaittujen keskiarvo - simuloitujen keskiarvo (bias) suuri. Testauksessa onkin syytä jakaa virhevarianssi harhasta, kulmakertoimesta ja satunnaisvaihtelusta johtuvaan.

Sulatusmallin testauksessa on käytetty suomalaista ja norjalaista dataa $(n=61)$. Sonnan orgaanisen aineen ennustevirhe kokeen sisällä oli $0.10 \mathrm{~kg} / \mathrm{pv}$ ja vastaavasti sulavan orgaanisen aineen saannin virhe 0.09 $\mathrm{kg} / \mathrm{pv}$ eli malli ennustaa erittäin hyvin dieettien väliset erot energian saannissa. Ohutsuoleen virtaavan valkuaisen ennustevirhe $78 \mathrm{~g} / \mathrm{pv}$, joka vastaa noin $50 \mathrm{~g}$ OIV:ta. Tulos osoittaa toisaalta paitsi sen, että malli ennustaa valkuaisen virtauksen ohutsuoleen erittäin hyvin myös sen, että testidata perustuu erittäin tarkasti tehtyihin mittauksiin. 
Tällä hetkellä metabolian mallintaminen ei ole vielä johtanut yhtä hyviin tuloksiin kuin ravintoaineiden saannin mallintaminen. Suurimmat ongelmat ovat maitomäärän ja maidon koostumuksen ennustamisessa; EKM, rasva- ja erityisesti valkuaistuotoksen vasteet ruokinnan muutoksille malli ennustaa jo nyt varsin hyvin. Suomalaisessa koeaineistossa $(n=76$ ruokintaa) EKM-tuotoksen kokeen sisäinen ennustevirhe oli $0.70 \mathrm{~kg} / \mathrm{pv}$ ja valkuaistuotoksen vastaavasti $19.6 \mathrm{~g} / \mathrm{pv}$. Kokeen sisäisestä valkuaistuotoksen vaihtelusta malli selitti yli $90 \%$. Hieman huonommat tulokset aineenvaihdunnan mallintamisessa johtuvat siitä, että monia säätelymekanismeja erityisesti ravintoaineiden jakautuminen maidon komponenttien kesken sekä kudosten ja maitorauhasen välillä ei tunneta kvantitatiivisesti riittävän hyvin.

Karolinen hyvät testitulokset verrattuna muihin vastaaviin malleihin perustuu useaan eri tekijään, joista seuraavassa tärkeimpiä: rehun valikoiva viipyminen pötsissä (2 poolin malli) on otettu huomioon NDF:n sulatuksen mallintamisessa (1), viipymisajan vaihtelun huomioon ottaminen (2), kd-faktori, joka ottaa huomioon dieetin koostumuksen vaikutuksen NDF:n sulatusnopeuteen (3), proteolyysin vaiheet otettu huomioon valkuaisen hajotuksessa (4), mikrobisynteesin mallintaminen (5) ja erittäin luotettava testidata (6).

\section{Herkkyys- eli sensitiivisyysanalyysi}

Herkkyysanalyysin tavoitteena on selvittää, miten simuloitu tulos (esim. ME-saanti, maitotuotos) muuttuvat suhteessa mallin parametrin muutokseen. Alla olevassa esimerkissä on testattu muutamien tärkeimpien parametrien vaikutusta ME:n ja OIV:n saantiin sekä EKM- ja valkuaistuotokseen. Dieetissä on säilörehua $60 \%$ ja väkirehua $40 \%$. Simulaatiossa lisättiin/vähennettiin $10 \%$ :lla säilörehun ja väkirehun INDF-pitoisuutta, DNDF:n sulatusnopeutta, liukenemattoman valkuaisfraktion (ISP) sulatusnopeutta, säilörehun liukenemattoman valkuaisen osuutta sekä tärkkelyksen sulatusnopeutta. Muiden parametrien arvot pidettiin vakiona. Analyysin tulokset on esitetty taulukossa 1.

Taulukko 1. Herkkyysanalyysin tulokset ilmaistuna vastemuuttujan muutos \%:na, kun parametrin arvoa nostettiin $10 \%: 11$.

\begin{tabular}{|c|c|c|c|c|c|c|c|c|c|}
\hline & & \multicolumn{4}{|c|}{ Säilörehu } & \multicolumn{4}{|c|}{ Väkirehu } \\
\hline & & INDF & DNDF- 1 & $\mathrm{SP}-\mathrm{kd}$ & ISP (osuus) & INDF & DNDF- & ISP - kd & Tärk - kd \\
\hline & Perustaso & 78 & 0.066 & 0.08 & 400 & 90 & 0.064 & 0.078 & 0.25 \\
\hline $\operatorname{OMD}(\%)$ & 72.46 & -0.55 & 1.06 & 0.00 & -0.01 & -0.35 & 0.33 & 0.01 & 0.03 \\
\hline ME (MJ/pv) & 232.0 & -0.51 & 0.98 & 0.00 & -0.01 & -0.32 & 0.31 & 0.01 & 0.02 \\
\hline OIV (g/pv) & 1993.7 & -0.47 & 0.98 & -0.35 & 0.78 & -0.28 & 0.30 & -0.76 & 0.17 \\
\hline EKM (kg/pv) & 33.37 & -0.63 & 1.23 & -0.08 & 0.30 & -0.39 & 0.39 & -0.17 & 0.05 \\
\hline Valk.tuotos (g/pv) & 1051.8 & -0.42 & 0.93 & -0.11 & 0.28 & -0.25 & 0.28 & -0.22 & 0.16 \\
\hline
\end{tabular}

Herkkyysanalyysin tuloksia voidaan käyttää hyväksi arvioitaessa, mitkä ovat mallin kannalta keskeisimmät asiat ja toisaalta arviomaan, mitkä parametrit rehuista kannattaa ensisijaisesti analysoida ja missä voidaan turvautua taulukkoarvoihin. Tässä analyysissä säilörehun INDF-pitoisuus ja DNDF:n sulatusnopeus osoittautuivat tärkeimmiksi ravintoaineiden saantiin ja tuotokseen vaikuttaviksi tekijöiksi. Tuloksia arvioitaessa on syytä myös ottaa huomioon, miten $10 \%$ :n muutos parametrin arvossa suhtautuu käytännön vaihteluväliin ja mitä muita mahdollisia vaikutuksia parametrin muutoksella on. Säilörehun INDF-pitoisuus vaihtelee normaalisti välillä 40 - $160 \mathrm{~g} / \mathrm{kg} \mathrm{ka}$, joten $7.8 \mathrm{~g} / \mathrm{kg}$ ka muutos INDF-pitoisuudessa on vain 6-7\% vaihteluvälistä, kun vastaava $10 \%$ :n muutos säilörehun sulatusnopeudessa vastaa noin $15 \%$ normaalista vaihteluvälistä (0.04 0.08 per $\mathrm{h}$ ). Siten parametrin normaaliin vaihteluväliin suhteutettuna INDF-pitoisuus on rehun tärkein ravintoarvoon vaikuttava tekijä. Käytännössä vapaalla säilörehuruokinnalla INDF:n merkitys on vielä suurempi, koska rehun syönti lisääntyy ja myös DNDF:n sulatusnopeus lisääntyy INDF:n vähentyessä.

On mielenkiintoista havaita, että muutokset rehuvalkuaisen ominaisuuksissa vaikuttavat jopa OIV:n saantiin vähemmän kuin muutoksen NDF:n ominaisuuksissa. Tämä johtuu siitä, että pötsissä fermentoituvan energian määrä ja sen seurauksena mikrobivalkuaisen tuotanto lisääntyvät. OIV:n saannin muutos kuidun ominaisuuksien muutosten tuloksena lisää valkuaistuotosta tehokkaammin kuin OIV:n saannin muutos valkuaisen hajotusnopeuden muuttuessa. Tämä johtuu sitä, että edellinen lisää myös energian saantia mutta valkuaisen hajoavuuden muutos ei siihen vaikuta. 


\section{Karolinen hyödyntäminen}

Karolinea ei ole tarkoitettu korvaamaan nykyisiä systeemejä vaan niiden täydentäjäksi. Perinteiseen ajattelutapaan verrattuna mallin etuna on se, että sen avulla voidaan arvioida myös vaikutukset tuotantoon. Koska malli ei vielä ennusta tuotosvasteita samalla tarkkuudella kuin ravintoaineiden saannin muutoksia, tuotosvasteiden ennustamiseen voidaan käyttää Karolinella ennustetun ravintoaineiden saannin ja tuotosparametrien empiirisiä riippuvuuksia. Em. aineistossa EKM-tuotoksen kokeen sisäinen ennustevirheet EKM- ja valkuaistuotoksessa olivat $0.60 \mathrm{~kg} / \mathrm{pv}$ ja $16.0 \mathrm{~g} / \mathrm{pv}$. Koska myös mitatuissa arvoissa on satunnaisvaihtelusta johtuvaa virhettä, tuloksia voidaan pitää varsin lupaavina. Empiiristen mallien ongelmana on kuitenkin se, että niitä ei voida soveltaa erilaisissa olosuhteissa kuin mistä alkuperäinen aineisto on peräisin.

Säilörehun ja koko dieetin kuiva-aineen syönti-indeksi on varsin helppo liittää Karolineen. Tällöin voidaan säilörehun laadun (D-arvo ja käymislaatu) sekä väkirehun määrän ja valkuaispitoisuuden muutosten vaikutukset ottaa huomioon uutta dieettiä suunniteltaessa. Tilalla neuvoja testaa ensin nykyisen dieetin vaikutukset ravintoaineiden saantiin, kun tiedetään rehujen syönti ja tarvittavat parametrit. Tämän jälkeen tehdään halutut muutokset dieettiin ja tarkastellaan muutoksia. Pääpaino tulee olla muutosten - ei absoluuttisten lukujen - tarkastelussa. Ruokinnan muutosten taloudellinen arviointi voidaan myös tehdä tarkastelemalla muutoksia.

Karolinea voidaan jo sen nykymuodossa hyödyntää rehun marginaalisen energia- ja valkuaisarvon laskentaan. Voidaan esimerkiksi tarkastella paljonko yksi ohran kuiva-ainekilo tuottaa lisää energiaa ja OIV:ta, kun se lisätään normaaliin lypsylehmän rehuannokseen (esim. 20 kg kuiva-ainetta, 40 \% väkirehua). Tämän tarkastelun avulla voidaan arvioida huomattavasti luotettavammin rehujen hintaa verrattuna taulukkoarvoihin lypsylehmien ruokintatasoilla.

Tällä hetkellä ehkä suurin Karolinen tyyppisten mallien etu on niiden lähes rajaton potentiaali parantaa systeemiä nykyisiin järjestelmiin verrattuna. Uusin rehun sulatukseen ja aineenvaihduntaan liittyvä tutkimustieto voidaan helposti liittää malliin. Samaten mallin avulla voidaan arvioida nykyisen tietämyksen suurimmat puutteet ja suunnata kokeellisen tutkimuksen ponnistelut näiden asioiden selventämiseksi ja siten hyödyntää Suomen todennäköisesti vähenevät tutkimusresurssit nykyistä paremmin.

Pohjoismaisella yhteistyöllä lypsylehmien mallintamisessa on päästy hyviin tuloksiin. Osaltaan tämä perustuu siihen, että kokeellista tutkimusta on eri maissa suunnattu palvelemaan pitkän aikavälin visioita tutkimuksen kehittämisestä. Edelleen monet tekevät perinteistä ja kuvailevaa tutkimusta, ehkä siksi että puuttuu todellinen visio tutkimuksen kehittämisestä. Mallintaminen ei poista kokeellisen tutkimuksen tarvetta, mutta sitä pitäisi entistä enemmän käyttää täsmäaseena ratkaisemattomien kysymysten selvittämiseen sen sijaan että käytetään resursseja merkitykseltään vähäisten asioiden selvittämiseen tuotantokokein.

Yhtenä esimerkkinä tutkimusresurssien tehottomasta käytöstä voi mainita rehuvalkuaisen hajoavuuden määrittämisen nailonpussimenetelmällä, joka kuten taulukossa 1 esitetty analyysi osoittaa on sittenkin ravintoaineiden saannin kannalta varsin marginaalinen tekijä. Onneksi meillä Suomessa tästä ymmärrettiin luopua jo runsaat 10 vuotta sitten ja tutkimusresursseja on suunnattu enemmän säilörehun D-arvon, NDF:n sulatusominaisuuksien, rehun virtauskinetiikan ja pötsin metabolian tutkimukseen ja siten pystytty tuottamaan mallin rakentamisessa tarvittavaa tietoa ja toisaalta luomaan valmiudet käytännön rehujen analytiikassa ottaa käyttöön Karolinen tai vastaavan mallin vaatimia uusia parametrejä. 